\title{
Ortaçağ Avrupa Siyaset Düşüncesinde Süreklilik ve Özgünlük: John Fortescue'nün Siyaset ve Yönetim Anlayışıııın Tarihselliği
}

\author{
Fatih Durgun \\ İstanbul Medeniyet Üniversitesi \\ fatih.durgun@medeniyet.edu.tr
}

öZ

Geç Ortaçağ İngiliz siyaset düşüncesinin en önemli ismi, yazdıkları halen tartışılmaya devam eden John Fortescue'dur. Lancaster ve York Hanedanları arasındaki Güller Savaşı olarak bilinen taht mücadelesinden dolayı İngiltere'nin siyasal ve toplumsal bir krizden geçtiği bir dönemde eserlerini yazan hukukçu ve devlet adamı Fortescue, Krallık Yönetimi (dominium regale) ile Siyasal ve Krallık Yönetimi (dominium politicum et regale) biçimlerini ayıran kavramsallaştırmasıyla siyasal düşünceler tarihine özgün bir katkı yapmıştır. Fortescue'nün düşüncesinde Krallık Yönetimi, kralın keyfî idaresini simgelerken, Siyasal ve Krallık Yönetimi biçimi, kralın karar alma sürecinde tebaasının rızasını gözetmesi ve İngiliz Örfi Hukuku'nun sınırları dışına çıkmaması anlamına gelir. İngiliz siyaset düşüncesinin Kıta Avrupa'sındakinden farklı olduğunu iddia edenlerce Fortescue'nün kavramsallaştırması, İngiliz anayasalcılığının açık bir göstergesi olarak değerlendirilmiştir. Öte yandan, seküler bir hukukçu olması nedeniyle, Fortescue'nün siyaset anlayışının teoloji merkezli geleneksel Ortaçağ siyaset düşüncesinden farklı olduğu id- 
dia edilmiştir. Böylece Fortescue'nün siyaset düşüncesinin tarihsel bağlamı ihmal edilmiştir. Bu çalışma Fortescue'nün siyaset düşüncesini tarihsel bağlamı içinde okumayı önermektedir. Yazının temel iddiası, Fortescue'nün siyaset düşüncesinin, düşünülenin aksine, gelecek nesillere hitap eden kuşatıcı bir niteliğe sahip olmadığıdır. Onun siyaset düşüncesi mevcut siyasal ve toplumsal krize bir çözüm önerisi olarak şekillenmiş, geleneksel Ortaçağ siyaset düşüncesinin kalıplarından çıkmayı amaçlamamıştır. Fortescue'nün düşüncesinin asıl değeri ise, Ortaçağ düşüncesi sınırlarından çıkmadan, yeni doğmakta olan profesyonel hukukçular zümresinin içinde bulunulan koşullara bakış açısını yansıtmasından kaynaklanmaktadır.

Anahtar kelimeler: John Fortescue, Geç Ortaçă̆, İngiltere, Siyaset Düşüncesi, Siyasal ve Krallık Yönetimi

\section{GİRİş}

Geç Ortaçağ siyaset düşüncesinin, Yüksek Ortaçağ’da Aquina'lı Tomasso (ö. 1274) tarafından formüle edilen ve kemikleşen Aristotelesçi yoruma dayanmakla birlikte, ondan daha ileri ve farklı bir içeriğe sahip olduğuna dair düşünce, siyaset düşüncesi metinlerinin zorlama biçimde, aslında ifade etmedikleri anlam ve bağlamlarda okunmasına neden oldu. ${ }^{1} \mathrm{Bu}$ zorlama okumaların en tipik örnekleri, Opusculum de natura legis naturae (Doğal Hukuk'un Doğası Üzerine, 1463), De Laudibus Legum Angliae (İngiltere Yasalarının Övgüsü, 1468-1471) ve Governance of England (İngiltere'nin Yönetimi, 1471) gibi Geç Ortaçağ’ın bir parçası olarak düşündüğü-

1 Çalışmanın ilerleyen bölümlerinde Aquina'lı Tomasso'nun Aristotelesçi siyaset düşüncesinden ne anlaşılması gerektiği tartışılacak olmakla beraber, Tomasso'nun Hiristiyan dünya tasavvuruyla Aristoteles'in XIII. yüzyılda Yunancadan Latinceye çevirisi ilk kez Flemenk din adamı Willem Van Moerbeke (ö. 1286) tarafından yapılan Siyaset ve İngiliz din adamı Robert Grosseteste (ö. 1253) tarafından çevrilen Nicomakos'a Etik adlı yapıtlarındaki siyaset anlayışını kaynaştırmaya çalıştığını ve ahlaki erdemlere sahip bir yöneticinin idaresi altında "kamu yararı" prensibinin uygulanabileceğini vurguladığını belirtmekte fayda vardır. 
müz XV. yüzyıl İngiltere'sinin günümüzde bilinen en önemli siyaset düşünürü John Fortescue'nun siyaset düşüncesini gösteren eserleri üzerine olanlardır. Fortescue’nün yazdıkları belirli bir dönemin ruhunu ve siyasal anlayışını yansıtmasıyla tarihsel metinler olmalarına karşın, sanki bütün çağları kuşatan ve modern İngiliz siyaset düşüncesinin ayırt edici vasıflarının bulunabileceği kaynaklar olarak değerlendirilmiştir. ${ }^{2}$

Hukuk ve devlet adamı olarak çeşitli görevler yapmış olan John Fortescue'nün yazdıklarına yönelik zorlayıcı okumalar hem Fortescue'nün şahsıyla hem de yazdığı metinlerde siyaset, yönetim ve hukuk alanında yaptığı yorumlarla ilgiliydi. John Fortescue her şeyden önce XV. yüzyıla ait bir İngiliz düşünürdü. Ortaçă̆ siyaset düşüncesini şekillendiren Aquina'lı Tomasso, Lucca'lı Ptolemy (ö. 1327) ve Roma’lı Giles (ö. 1316) gibi isimlerden farklı olarak, bir ilahiyatçı değildi. Geç Ortaçağ'da bürokratik devletin artan gücü din adamları sınıfının dışında devlet kademelerinde görevlendirilebilecek profesyonel hukukçular zümresinin doğuşuna yol açmıştı. Tıpkı tarih yazıcılığının manastırlardaki keşişlerden seküler tarihçilere geçişi gibi, siyaset düşüncesi üzerine kalem oynatanların kimliğinde de çeşitlenme meydana gelmişti. Fortescue seküler bir hukuk adamı olarak yetişmişti. Geç Ortaçağ İngiltere'sinde üniversitelerden ve Kilise okullarından ayrı olarak, hukukçu ihtiyacını karşılamak üzere tüzel kişilik edinerek ortaya çıkan Londra'daki Hukuk Hanları'ndan (Inns of Court) en eskisi olan ve hakkındaki ilk resmî kayıtlara 1422 yılında rastlanan Lincoln's Inn' de yetişmişti. ${ }^{3}$

2 John Fortescue'nün siyaset düşüncesine ilişkin eserlerinin en yeni edisyonunu yapan Lockwood, Fortescue ile ilgili yanlış anlaşılmaların aşılmaya başladığı konusunda iyimser olsa da, metin içinde ve dipnotlarda gösterileceği gibi, bu konudaki sorunlu ve anakronik yaklaşım devam etmektedir. Shelley Lockwood, Sir John Fortescue: On the Laws and Governance of England (Cambridge: Cambridge University Press, 2002), xv-xvi. Bu çalışmada kullanılan Lockwood'un edisyonunda sırasıyla De Laudibus Legum Angliae (İngiltere Yasalarının Övgüsü) In Praise of the Laws of England başlığıyla ss. 3-80, The Governance of England (İngiltere'nin Yönetimi), ss. 83-123 ve Opusculum de natura legis naturae'nin (Doğal Hukuk'un Doğası Üzerine) siyaset konumuza ilişkin bölümleri Appendix A: Extracts from On the Nature of the Law of Nature başlığıyla ss. 127-136 arasında bulunmaktadır.

3 Hukuk sistemi ve bürokrasinin merkezileşmesiyle birlikte bu hukuk kurumları, Londra'ya gelen hukukçuların şehirde toplandıkları mekânlar olarak doğmuşlardı. Zaman içinde ise eğitim kurumu niteliğini kazandılar. Lincoln's Inn' in yanı sira Gray's Inn, Middle Temple ve Inner Temple gibi diğer örnekleri de zikredebiliriz. Nicholas Orme, "Education and Recreation,"

\section{Dîvân}

2016/2 
Bu farklı eğitim, din merkezli bir hukuk anlayışından daha çok İngiliz örfi hukukuna (common law) dayalı bir eğitim alması nedeniyle, Fortescue'nün metinlerinin seküler bir içeriğe sahip olduğu düşüncesini perçinledi. ${ }^{4}$ Bunun yanı sıra, Fortescue'nün XV. yüzyıl İngiliz siyasetinde siyasetçi kimliğiyle oynadığı rol de dikkat çekiciydi. Fortescue siyasi kariyer basamaklarını kolayca çıkmayı başarmıştı. 1421-1436 yılları arasında İngiliz Parlamentosu'nda görev almıştı. Hukukçu kimliğine itibar edilen biri olarak, 1442 yılından Lancaster Hanedanı'na mensup son kral VI. Henry'nin tahtı kaybettiği 1461 yılına kadar, Kraliyet Mahkemesi Başkanlığı görevini yürütmüştü. Bu görev onun İngiltere'nin idari, hukuki ve toplumsal yapısını daha iyi tanımasına olanak vermişti. Siyasi olarak onu önemli bir isim kulan görevlerden bir tanesi de, VI. Henry'nin Fransa'ya sürgüne gittiğinde yanında Lord Chancellor (Lordlar Kamarası Başkanı) olarak bulunmasıydı. ${ }^{5}$ Son Lancaster Kral VI. Henry'nin oğlu Prens Edward 1471 yılında Tewkesbury Savaşı'nda öldürülünce, Fortescue York Hanedanı mensubu yeni kral IV. Edward'ın yönetimine boyun eğmiş ve Kral'ın Danışma Meclisi'nde (council) yer almıştı. ${ }^{6}$ Pragmatik bir hukukçu ve siyaset adamı olan Fortescue'nün bütün bir kariyeri düşünülünce, siyaset düşüncesi bağlamında yazdıkları oldukça cezbedici bir hale gelir. Böylesine parlak bir siyasal kariyere sahip olan ve yeni koşullara ayak uydurmayı bilen Fortescue'nün siyaset düşüncesine ilişkin ne yazdığı konusunda beklenti doğal olarak oldukça yüksek olmuştur.

Gentry Culture in Late Medieval England, ed. Raluca Radulescu ve Alison Truelove (Manchester: Manchester University Press, 2005), 63-83, 74. Ayrica bkz. Nicholas Orme, Medieval Schools: From Roman Britain to Renaissance England (New Haven: Yale University Press, 2006), 56.

4 Fortescue'nün metinleriyle ilgili zorlayıcı yaklaşımın halen devam ettiğine dair en iyi kanıtlardan biri Ortaçağ ve Yeniçă̆ Avrupa siyaset düşüncesi üzerine çalışmalarıyla tanınan Cary J. Nederman'nın ifadelerinde görülebilir. Nederman, Tomasso'nun Aristotelesçi siyaset düşüncesinin etkisi altında yazdığını kabul ettiği Fortescue'nün modern çağımıza hitap eden bir "vatandaşlık” anlayışı geliştirdiğini, siyaset düşüncesi açısından hukuk adamlarının "devlet idaresindeki otoritelerinin din adamlarının manevi hayatın idaresine ilişkin meselelerdeki otoritelerine eşit" olmasını gerektiren bir yönetim anlayışına sahip olduğunu iddia etmektedir. Cary J. Nederman, "From Moral Virtue to Material Benefit: Dominium and Citizenship in Late Medieval Europe," Cultivating Citizens: Soulcraft and Citizenship in Contemporary America, ed. Dwight D. Allman ve Michael D. Beaty (New York: Lexington Books, 2002), 43-60.

5 Lockwood, “Introduction”, xviii.

6 Lockwood, "Introduction”, xix. 
Fortescue'nün, siyasal tecrübelerini teorik yaklaşımıyla kaynaştırarak yeni bir siyaset düşüncesi geliştirmesi bu beklentinin odağında yer almıştır.

Fortescue'nün kişisel kariyeri bir yana, eserlerini yazdığı dönem de bu beklentiyi artıran nedenlerden biridir. XV. yüzyıl Ortaçağ ile Yeniçağ arasında bir geçiş dönemi olarak görüldügüunden, bu dönemde, yani siyasal ve toplumsal bir krizin İngiltere'yi kasıp kavurduğu bir devirde yazılanların eskilerin yazdıklarından farklı bir şeyler söylemesi beklenebilirdi. Böylece Yeniçağ siyaset düşüncesinin teolojiden bağımsız ve seküler olduğu addedilen cumhuriyetçi ya da çoğulcu sivil siyaset anlayışına kapı açacak fikir ve tezler en azından nüve halinde bulunabilirdi. Fortescue, siyaset düşüncesine ilişkin yazdıklarını devlet adamı olarak içinde yer aldı̆̆ı, Lancaster ile York Hanedanları arasında Güller Savaşı (1455-1485) olarak bilinen İngiliz taht mücadelesinin olduğu yıllarda kaleme almıştı. $\mathrm{Bu}$ anlamda, bütün bir siyasal toplumu etkileyen kriz ortamının yönetim, meşruiyet ve hukuk temaları etrafında, Fortescue'nün İngiliz siyaset ve hukuk sisteminin özgünlüğüne yaptığı vurguya neden olduğu ve bunun modern İngiliz anayasal sisteminin fikri zeminini oluşturduğu düşünülüyordu. ${ }^{7}$

John Fortescue’nün Geç Ortaçağ siyaset düşüncesine yapmış olduğu en önemli ve orijinal denilebilecek katkı Krallık Yönetimi (dominium regale) ile Siyasal ve Krallık Yönetimi (dominium politicum et regale) arasında yaptığı ayrımda görülmüştür. ${ }^{8} \mathrm{Bu}$

$7 \mathrm{Bu}$ yaklaşım tarzı Fortescue'nün siyaset düşüncesini derli toplu özetlemesine rağmen, M. R. L. Kelly tarafından yazılan konuyla ilgili kaleme alınmış en son çalışmalardan birinde de göze çarpar."Sir John Fortescue and the Political Dominium: The People, the Common Weal, and the King," Constitutions and the Classics: Patterns of Constitutional Thought from Fortescue to Bentham, ed. D. J. Galligan (Oxford: Oxford University Press, 2014), 5185. Fortescue'nün İngiltere'de Yeniçağ'daki anayasalcı düşüncelere zemin hazırladığı konusunda daha eski bir çalışmadaki yorumlar için bkz. Quentin Skinner, The Foundations of Modern Political Thought: The Age of Reformation 2 (Cambridge: Cambridge University Press, 2004), 54-56. Öte yandan, bir diğer yaklaşım biçimi olarak Fortescue'nün yazdıklarını basit birer propaganda metni olarak görme eğilimi, hem onun pragmatik bir siyasetçi olarak İngiliz taht kavgalarında taraf değiştirmesi, hem de siyasal bir kaos dönemi olarak değerlendirilen XV. yüzyll İngiltere'sine ilişkin olumsuz düşüncelerden kaynaklanıyordu. Bu konuda bkz. P. E. Gill, "Politics and Propaganda in Fifteenth- Century England: the Polemical Writings of Sir John Fortescue," Speculum 46 (1971): 337-347.

8 Fortescue'nün siyaset düşüncesinin tarihselliğine dikkat çeken, bu anlamda onun Ortaçağ siyaset düşüncesiyle sürekliliğini gören, ancak yine de

Dîvân

2016/2 
ayrım meşru ve adil bir hükümdarın almış olduğu kararlarda tebasının rızasını gözetmek zorunda olduğu düşüncesine dayanır. Fortescue'nün anlayışına göre, Krallık Yönetimi, kralın hükmettiği topraklar üzerinde keyfî idaresini ifade ediyordu. Siyasal ve Krallık Yönetim Biçimi ise, Kral'ın iradesinin karar alma süreçlerinde nihai olarak belirleyici olduğu, fakat siyasal toplumun Kral ve tebaası arasında bir mutabakata dayandığını gösteriyordu. Mutabakat dinî, tarihsel ve hukuki ve bir niteliğe sahipti. Dinîydi, çünkü Kutsal Kitap'ın ve siyaset düşüncesi üzerine yazan Aquina'lı Tomasso gibi ilahiyatçıların idealize ettikleri siyasal yönetim biçimi buydu. Tarihseldi, çünkü İngiltere'nin kadim tarihinin de gösterdiği üzere İngiliz siyasal toplumu bu anlayış temelinde kurulmuştu. Hukukiydi, çünkü İngiliz örfi hukuku bu ayrıma göre şekillenmişti.

Fortescue'nün belli başlı eserlerinde yapmış olduğu bu ayrım, yukarıda örnek verdiğimiz gibi, Ortaçağ siyaset düşüncesine aşina olanları ve konu üzerine düşünenleri oldukça uzun bir süredir meşgul etmeye devam etmektedir. Bunun temel nedeni, Ortaçağ düşüncesinde en azından teorik olarak kabul edilen, kralın belirli bir hukuki çerçeve içerisinde tebaasının haklarını gözeterek hareket etmesi gerektiği düşüncesini yeni bir kavramsallaştırmayla gündeme getirmesidir. İçeriği özgün olmakla birlikte, Siyasal ve Krallık Yönetim Biçimi kavramı Ortaçağ siyaset düşüncesinde Aquina'lı Tomasso ve Lucca'lı Ptolemy'nin tohumlarını attığı bir düşüncenin olgunlaşmış halidir. Öte yandan, Fortescue'nün seküler bir paradigma çerçevesinde siyaset düşüncesini geliştirdiği ve kendinden önceki düşünce geleneğiyle kopuş içinde olduğu, oldukça sorunlu bir yaklaşımdır. Kutsal Kitap ve Ortaçağ skolâstik geleneğinde yazılmış olan eserlere verilen referansları dikkate alındığında, bu daha açık biçimde görülür. Bu çalışmada bütün bunlar

yazdıklarını büyük oranda siyaset teorisi sınırlarında değerlendiren temel çalışmalar: S. B. Chrimes, "Sir John Fortescue and His Theory of Political Dominium," Transactions of the Royal Historical Society, 4. Seri, 17 (1934): 117-147; Felix Gilbert, "Sir John Fortescue's Dominium regale et politicum," Medievalia et Humanistica 2 (1944): 88-97; J. H. Burns, "Fortescue and the Political Theory of Dominium," Historical Journal 28 (1985): 777-797. Fortescue'nün yapıtları üzerine bazı eski çalışmalara örnek olarak: R. W. K. Hinton, "English Constitutional Doctrines from the Fifteenth Century to the Seventeenth: I. English Constitutional Theories from Sir John Fortescue to Sir John Eliot," EHR 75 (1960): 410-442; Arthur B. Ferguson, "Fortescue and the Renaissance: A Study in Transition," Studies in the Renaissance 6 (1959): 175-194; Charles F. Arrowood, "Sir John Fortescue on the Education of Rulers,” Speculum 10 (1935): 404-410. 
dikkate alınarak, Fortescue'nün siyaset düşüncesinin bağlamı düşünüldüğünde tarihsel bir niteliğe sahip olduğu, bu nedenle de tarihselliği içinde değerlendirilmesi gerektiği vurgulanacak, Ortaçağ siyaset düşüncesi içinde geçmişte yazılanlarla içerdiği süreklilikler gösterilecek ve sonraki dönemlerin siyaset düşüncesini belirlemek kaygısıyla bir meta-anlatı önermediği tartışılacaktır. ${ }^{9}$

\section{Fortescue'nün Siyaset Düşüncesi: Siyasal ve Krallık Yönetim Biçimi (Dominium Politicum Et Regale)}

John Fortescue'nün Krallık Yönetimi ile Siyasal ve Krallık Yönetimi arasında yapmış olduğu ayrım ilk olarak 1463 tarihli Opusculum de natura legis naturae (Doğal Hukuk'un Doğası Üzerine) başlıklı eserinde karşımıza çıkar. Burada kavramın Fortescue'nün siyaset düşüncesi için, eserin teorik ve felsefi yapısına uygun olarak ne ifade ettiği gayet açık bir biçimde ortaya konur. İki yönetim biçimi arasında ayrım yapmayı ve farklılıkları ortaya koymayı gerekli gören Fortescue kralların, İngiliz Parlamentosu içinde söz hakkına sahip olan din adamları, soylular ve avam kitlesinin, yani Ortaçağ siyasal toplum hiyerarşisinin bilinen ve dönemin kayıtlarında kullanılan şekliyle, “Üç Zümre'nin rızası olmadan ne kanun yapabileceğini ne de tebasına yükümlülükler dayatabileceğini” iddia etmektedir. Bu noktada, bir adım daha ileri giderek, Krallık yargıçlarının gelenekle teminat altına alınmış bir bağımsızlık alanlarının bulunduğunu da vurgular. Fortescue'ye göre "hükümdar aksine emirler vermiş olsa bile, Krallık hukukçularının ülkenin hâlihazırdaki kanunlarına tezat hüküm vermeyeceklerine dair ye-

9 Fortescue'nün siyaset düşüncesinin modern tarih yazımında alımlanmasına ilişkin sorunlar konusunda değerlendirmeler için bkz. Alan Cromartie, "Common Law, Counsel and Consent in Fortescue's Political Theory," The Fifteenth Century IV: Political Culture in Late Medieval Britain, ed. Linda Clark and Christine Carpenter (Woodbridge: The Boydell Press, 2004), 4568; özellikle, 45-48. Cromartie'nin çalışmasının temel problemi, bu çalışmanın esas iddiası olan Fortescue'nün siyaset düşüncesinin tarihselliğini göz ardı etmesi ve Fortescue'yu sadece bir siyaset teorisyeni olarak okumaya çalışmasıdır. Fortescue'nün siyaset düşüncesinin tarihselliğini bağlama oturtmak açısından en faydalı eser XV. yüzyıl İngiliz tarihini dönemin kendi kavramlarıyla okumaya çalışan John Watts'a aittir: Henry VI and the Politics of Kingship (Cambridge: Cambridge University Press, 1996).

Dîvân

2016/2 
min ettiklerini” belirtir. ${ }^{10}$ Fortescue yaptığı ayrımın bir tür üçüncü yol anlamına geldiğinin farkındadır. Siyasal otorite (dominium) Kral'dan ayrı olarak konumlandırdığı çoğunluğun elinde değildir. Çünkü "tebaa, Kral'ın otoritesi olmadan, kendi başına yasa yapamaz." Öte yandan, Kral'ın mutlak otoritesine dayalı bir siyasal yönetim tarzından bahsetmek de mümkün değildir. ${ }^{11}$ Daha önce vurguladığımız üzere, Fortescue'ya göre kadim İngiliz örfi hukuk geleneği (common law) bunun önündeki en büyük engeldir.

Fortescue, ne Krallık ne de Siyasal yönetim olmayan, fakat bunların her ikisinin birlikteliğine dayanan Siyasal ve Krallık Yönetimi Biçimi kavramını, siyaset düşüncesi bağlamında önemli olan diğer eserlerinde de vurgulamıştır. Lancaster Hanedanı'nın son kralı VI. Henry'in oğlu Edward için 1468-1471 yıllarında yazdığı nasihatname türündeki De Laudibus Legum Angliae (In Praise of the Laws of England, İngiltere Yasalarının Övgüsü) adlı eserinde, İngiltere'yi yöneten kralın "Krallığının yasalarını kendi arzusuna göre değiştiremeyeceğini" belirtir. ${ }^{12}$ Fortescue'ye göre bunun nedeni İngiliz kraliyet sisteminin sadece krallığa değil, hem Krallık hem de Siyasal ve Krallık Yönetimi'ne dayanmasıdır. Bu eserinde, kral adayı olan Edward'a İngiliz örfi hukuk sistemini ve özgünlüklerini tanıtmayı amaçlayan Fortescue, ilerleyen satırlarda değineceğimiz gibi, konuya bu eserin başka kısımlarında da yer vermiştir. De Laudibus, savaştan başka bir şeye ilgi duymayan bir Kral adayına, yönetmeye aday olduğu ülkenin geleneksel hukuk yapısını anlatmak ve nasıl bir idareci olması gerektiğini genel hatlarıyla göstermek hedefindedir. ${ }^{13}$ Eserin sadece pratik siyasete ilişkin bir nasihatname niteliğinde olmadığı, içeriğinin büyük bir kısmının İngiliz örfi hukuku üzerine açıklamalara ayrılmasından anlaşılabilir.

Fortescue, Krallık Yönetimi ile Siyasal ve Krallık Yönetimi arasında yaptığı ayrıma, son olarak 1471 yılında tamamladığı Governance of England (İngiltere'nin Yönetimi) adlı eserinde yer verir. Latince yazdığı diğer iki eserinin aksine İngilizce kaleme aldığı bu

10 Fortescue, Extracts from On the Nature of the Law of Nature, 128.

11 Fortescue, In Praise of the Laws of England, 17-18; Burns kavramın tarih içinde geçirdiği değişime vurgu yapar: "Fortescue," 777-797, 778.

12 Fortescue, In Praise of the Laws of England, 47.

13 Fortescue, De Laudibus'un henüz başlarında "Prens olgunlaşır olgunlaşmaz kendisini tamamen askeri talimlere verdi." diyerek bu saptamada bulunur. Fortescue, In Praise of the Laws of England, 3. Adaletle yönetebilmek için prens geleneksel hukukun genel kaidelerini bilmelidir. Fortescue, In Praise of the Laws of England, 4, 78-79. 
çalışmada, Opusculum de natura legis naturae'de yaptı̆̆ gibi açık ifadelerle kavramı tanımlar. Eserinin hemen girişinde bir krallığın yönetiminin iki temel şekli olduğunu; bunlardan birinin kralın Hanedan'dan gelen veraset hakkına dayalı Krallık Yönetimi, diğerinin ise kralın tebaasının haklarıyla Kral'ın iradesinin dengesine dayalı Siyasal ve Krallık Yönetimi biçimleri olduğunu söylemektedir. Birincisinde, kral tebaası üzerinde kendi yaptığı kanunlara göre bir yönetim uygular ve tebaanın rızasını gözetmeye gerek duymaz. Aslolan, kralın kendi iradesidir (voluntas, will). İkinci yönetim şeklinde ise kral, tebaasının rızasını gözetmek durumundadır. Keyfi uygulamalar tebaanın iradesiyle aynı görülen, siyasal toplumun bir kral etrafında belirli hukuk kaideleriyle bütün bir toplum tarafından kurulması sebebiyle, örfi hukuk tarafından sınırlandırılır. ${ }^{14}$

\section{Fortescue'nün Siyasal Yönetim Anlayışı: Süreklilik ve Özgünlük}

John Fortescue'nün Krallık Yönetimi ile Siyasal ve Krallık Yönetimi'ne ilişkin bu tanımları nasıl değerlendirilmelidir? Fortescue'nün eserlerini yazmış olduğu siyasal bağlam göz önüne alındığında, yaptığı kavramsallaştırma Ortaçağ siyaset düşüncesi içerisinde nereye oturmaktadır? Bu sorulara cevap verebilmek için Fortescue'nün, sıkça atıf yaptığı kendinden önceki siyaset düşüncesi yazarlarını nasıl okuduğu konusuna eğilmek gerekir. Ortaçağ siyaset düşüncesi geleneği içinde değerlendirilmesi gereken Fortescue, yapmış olduğu bu kavramsal ayrımı meşru bir zemine oturtma ihtiyacı duyar. Bu nedenle, Klasik Ortaçağ siyaset düşüncesinin temel metinlerini kendi teorik iddialarına dayanak yapar. Bu tutum geleneğin itibar gördüğü ve düşüncede sürekliliğin esas olduğu Ortaçağ Avrupa düşünce paradigması içinde makul bir tavırdır. Fortescue'nün geçmiş yazarların eserlerine yaptığı vurgu kendi metinlerinde öyle baskındır ki, siyaset düşüncesinde ortaya

14 Fortescue, The Governance of England, 83-87. Fortescue'nün siyaset düşüncesi için kaynak teşkil eden bahsettiğimiz üç eserden Opusculum de natura legis naturae'nin konumuzla ilgili bölümleriyle diğer iki eserin tam metin edisyonları, daha önce de belirttiğimiz üzere, 2 numaralı dipnotta atıf yaptığımız Fortescue'nün eserlerine ilişkin en yeni edisyon-kritik olan Lockwood'un çalışmasında yapılmıştır. Makalede bu edisyon esas alınmıştir.

Dîvân

$2016 / 2$ 
koyduklarının özgünlüğünü değerlendirmek, ancak onu öncekilerle karşılaştırarak mümkün olur.

Öte yandan, Yüksek Ortaçağ’’n skolastik mantığı Fortescue'nün metodolojisini şekillendirmiştir. Skolastik metodolojinin gerek Geç Ortaçağ ve Rönesans gibi geçiş dönemlerine, gerekse de modern düşünce biçimine bıraktı̆̆ı en belirgin miraslardan biri kavramları kesin ve açık sınırlılıklarıyla tanımlamaktır. Bir kavram bütün yönleriyle açıklanmalıdır. Bu açıdan Ortaçağ skolastik yöntemi, Hıristiyanlık ve Antikite metinlerinde geçen kavram ve sorunlara ilişkin "tutarlı cevaplar üreten bir kavramsal sistem" meydana getirmiştir. ${ }^{15}$ Ortaçağ siyaset düşüncesindeki bu iki yönelime sıkı sıkıya bağlı olan Fortescue, Krallık Yönetimi ve Siyasal ve Krallık Yönetim biçimleriyle neyi kast ettiğini açıklamak için, Ortaçağ siyaset düşünce geleneği içinde düşünen ve yazan birinden bekleneceği üzere, Aquina'lı Tomasso'nun konuya ilişkin yaptığı yorumlardan yararlanma yoluna gider.

Krallık Yönetimi ile Siyasal ve Krallık Yönetimi arasında çizdiği ayrımı kendi açısından kesinlikle özgün olarak tanımlamayan Fortescue, Aziz Aquina'lı Tomasso'nun eserlerinde bu ayrımın var olduğunu iddia eder. Fortescue'nün bu konuda başvurduğu kitap, Tomasso'nun Kıbrıs Kralı Hugues II de Lusignan (ö. 1267) için yazdığı ve Kral'ın ölümü sebebiyle tamamlamadığı De Regno (Krallık Üzerine) başlıklı eserdir. ${ }^{16}$ Özellikle Aristoteles' in siyasal toplumun doğası üzerine yazdıklarının etkisinde olan Tomasso, bir toplumda birlikte yaşamanın doğal olduğunu, "herkesin kendi çıkarının peşine düşeceği” topluluk yaşamında "toplumun bütün üyelerinin iyiliğini gözetecek" bir yönetici otoriteye ihtiyaç olduğunu vurgulamaktadır. ${ }^{17}$

15 Robert E. Goss, "The First Meeting of Catholic Scholasticism with dGe lugs Pa Catholicism," Scholasticism: Cross-Cultural and Comparative Perspectives, ed. José Ignacio Cabezón (New York: State University of New York Press, 1998), 65-90, 67.

16 Aslında Fortescue, eserini tamamlamayan Tomasso'nun öğrencisi Lucca'lı Ptolemy tarafından bitirilen ve Regimine Principum (Hükümdarların Yönetimi Üzerine) adıyla Geç Ortaçağ'da bilinen eseri de kendisine kaynak olarak kullanmaktadır. Eserin bir kısmını Tomasso'nun yazdığı kabul edilmektedir. Muhtemelen değişik kopyalar Fortescue'nün elinde mevcuttu. J. H. Burns, Fortescue'nün Tomasso adına yaptığı referansların Ptolemy'e ait olduğunu iddia eder: "Fortescue and the Political Theory of Dominium," 777-797, 782. Gilbert, "Sir John Fortescue's Dominium regale et politicum," 88-97, 92-93.

17 Thomas Aquinas, De Regno Ad Regem Cypri, çev. Gerald B. Phelan, gözden geç. I. Th. Eschmann (Toronto: The Pontifical Institute of Mediaeval Stu- 
Bu anlamda, "kamu maslahatı" (bonum commune) ${ }^{18}$ vurgusu yapan Tomasso, bir kişi, yani kral tarafından yönetilmenin "doğal," dolaylsıyla da makul olduğunu; evrene bakıldığında "bütün her şeyi yaratan ve yöneten bir Tanrı" olduğunu belirtir. ${ }^{19}$ Tomasso'nun Ortaçağ siyaset düşüncesine özgün katkılarından biri, Krallık Yönetiminin anarşik bir toplumsal düzene yol açma tehlikesini içeren çoğunluk yönetiminden daha doğru olduğunu belirtmekle birlikte, tebaasının görüş ve taleplerini hiçe sayan yöneticinin tiranlaşacağı tehlikesine dikkat çekmesidir. Kendi ifadesiyle, "Bir Kral'ın yönetimi en iyisi olduğu gibi, bir tiranın yönetimi de en kötüsüdür.” ${ }^{20}$ Aquina’lı Tomasso'nun öğrencisi Lucca'lı Ptolemy, hocasından çok daha ileri giderek, Krallık Yönetimi ve Siyasal Yönetim olarak yaptığı ayrımda, ilkini despotik idareyle özdeşleştirirken, ikincisinin daha iyi olduğunu iddia eder. Krallık Yönetimi köleliğe yol açarken, "liyakat" temelli Siyasal Yönetim, "bilge ve erdemli" insanlar için uygun olanıdır. ${ }^{21}$

Ptolemy'nin yaptığı ayrımın bilincinde olan ve bu ayrımdan yararlanan Fortescue, mutedil bir çözüm yolu olarak, hem Krallık hem de Siyasal Yönetim'i barındıran bir idare biçimini Krallık ve Siyasal Yönetim kavramsallaştırmasıyla önerir. Fortescue, Kral'ın gücünün siyasal toplumun oluşturduğu hukuk kaideleriyle, yani kadim hukuk (political law) geleneğiyle sınırlandırılması gerektiğini söyler. ${ }^{22}$ Fortescue'nün Ortaçağ düşünce geleneğinin en çok itibar edilen düşünürü Aquina'lı Tomasso'dan yararlanarak kendi kavramsallaştırmasını meşru bir zemine oturtmak istediği aşikârdır. Ancak, Fortescue'nün Tomasso'nun "kamu maslahatı” üzerine düşüncelerini, siyasal toplumun hukuk kaideleriyle sınırlandırması gerektiği yönündeki yorumu aşırı bir okumadır. Aslında Fortescue da Aquina'lı Tomasso'nun XIII. yüzyıl dünyasına ait si-

dies, 1949), http://dhspriory.org/thomas/DeRegno.htm (eriş. tar. 15 Aralık 2016). İnternet sitesinde, kullanılan edisyon kitabın başlı̆̆ı ve içeriği verilmekle birlikte sayfa numaraları belirtilmemiştir.

18 Aquinas, De Regno, Book I, Chapter 1:8. http://dhspriory.org/thomas/DeRegno.htm (eriş. tar. 15 Aralık 2016).

19 Aquinas, De Regno, Book I, Chapter 3:19. http://dhspriory.org/thomas/ DeRegno.htm (eriş. tar. 15 Aralık 2016).

20 Aquinas, De Regno, Book I, Chapter 4.21. http://dhspriory.org/thomas/ DeRegno.htm (eriş. tar. 15 Aralık 2016).

21 Ptolemy of Lucca, On the Government of Rulers, de Regimine Principum, çev. James M. Blythe (Philadelphia: University of Pennsylvania Press, 1997), Book 2: 124.

22 Fortescue, In Praise of the Laws of England, 17-18. 
12

Dîvân

$2016 / 2$ yaset düşüncesinin, kendisine yeterli temel sağlayamayabileceğini görmüștür. Bu nedenle, Krallık Yönetimi ile Siyasal ve Krallık Yönetimi olarak yaptığı ayrımın Tomasso'nun eserinde var olduğunu iddia etmeye devam etmekle birlikte, bu kavramsallaştırmanın siyaset düşüncesi üzerine yazan başka düşünürlerce daha açı biçimde tanımlandığını ifade etmiştir. Tomasso'nun öğrencisi olan, Ortaçağ'ın büyük düşünür ve din adamlarından Roma'lı Giles'in siyasal yönetime ilişkin düşüncelerini buna örnek gösterir. ${ }^{23}$ Gerçekten de Giles hocası Tomasso'nun düşüncelerini geliştirmiş ve Geç Ortaçağ siyaset düşüncesini derinden etkilemiştir. Krallık Yönetimini tek meşru yönetim biçimi olarak gören Giles, Tomasso'dan daha net olarak, Kral'ın yasalarla sınırlandırılması gerektiğini belirtmiştir: "Mümkün olduğunca fazla şeyin hukukla belirlenmesi ve mümkün olduğunca az şeyin Kral'ın keyfî yargısına bırakılması uygundur." ${ }^{24}$ Ancak, Fortescue'nün kavramsallaştırmasını metninde kullanmamıştır. Özetle, siyasal krizden çıkışa uygun bir yönetim sisteminin nasıl olması gerektiğine kafa yoran Fortescue için, hem Tomasso'nun hem de Giles'in yazdıkları kendi siyaset düşüncesini geleneğe referansla kurma ve meşrulaştırma çabasında da belirleyici olmuştur.

Fortescue Ortaçağ düşünce geleneği içinde Krallık Yönetimi konusundaki temel yaklaşımları değerlendirdikten sonra, adlarından söz ettiğimiz üç eserinde de skolastik metodolojinin gereği olarak bahsettiğimiz kavramı açık seçik tanımlama çabasına girişir. Fortescue bunun için bir kralın Krallık Yönetimini Siyasal Yönetime neden tercih ettiği sorusunu gündeme getirir. ${ }^{25}$ Her üç eserde de Eski Ahit'e göndermelerde bulunarak teo-politik okumayı ihmal etmeyen Fortescue, De Laudibus ve Governance'da keyfi biçimde işleyen Krallık Yönetiminin ilk örneği olarak Nemrud'u gösterir. Fortescue'nün “tiranların ilki” ${ }^{26}$ olarak dikkati çektiği Nemrud, kimliği konusunda kesin bir bilgi olmamakla beraber, Hz. Nuh'un soyundan gelen Mezopotamyalı (muhtemelen Asur) bir kral olarak bilinir. Nemrud, Eski Ahit'in Yaratılış (Genesis) Bölümü'nde tiran örneği olarak gösterilmiştir. Yaratılış'ın 10. Bölümü'ndeki anlatıya

23 Fortescue, The Governance of England, 84; Fortescue, Extracts from On the Nature of the Law of Nature, 128.

24 Alıntı için bkz. James M. Blythe, Ideal Government and the Mixed Constitution in the Middle Ages (Princeton: Princeton University Press, 1992), 70.

25 Fortescue, The Governance of England, 85.

26 Fortescue, In Praise of the Laws of England, 19; Fortescue, The Governance of England, 85. 
göre, ilk önceleri "yiğitliğiyle” tanınan Nemrud'un bu vasfı dolayısıyla "Rabb'in önünde yiğit bir avcıydı" sözüne mazhar olduğu, zaman içinde gücünü arttırarak Asur ülkesine gidip Ninova ve birkaç başka şehri kurduğu belirtilmektedir. ${ }^{27}$ Nemrud'un tiranlıkla özdeşleştirilen bir tarihsel figür haline gelmesi ise zamanla Yahudi anlatı geleneği içinde gerçekleşmiştir. Hristiyan düşüncesinin Yahudi geleneği üzerinde inşa edildiği düşünüldüğünde, Nemrud'un kötü olanla özdeşleştirilmesi anlaşılır. Bu konuda Aziz Augustinus ve Sevilya'lı İsidore gibi, Hristiyan düşüncesinin kurucu isimleri yorumlarda bulunmuşlardır. Augustinus'a göre Nemrud, Tanrı'ya karşı gelen "dev bir avcıdır." ${ }^{28}$ İnsanlardan farklı bir yapıya sahip olan "dev"lerin varlığını kabul eden Augustinus, ${ }^{29}$ cüsseli olması ${ }^{30}$ ve şiddet eğilimi nedeniyle böyle adlandırdığı Nemrud'un tiranlığı konusuna doğrudan değinmemektedir.

Nemrud'un anlatı içindeki işlevi, kibir sahibi olmanın büyük bir günah olduğunu ve Tanrı'ya giden yolun “alçakgönüllülük”ten geçtiğini vurgulamaktır. Nemrud, Babil Kulesi'ni Tanrı'ya karşı kibrinin bir göstergesi olarak yaptırmış ve "cezayı hak etmiştir." Sevilya'lı İsidore'nin (ö. 636) Ortaçağ skolastik düşüncesini şekillendiren Etymologiae (Etimolojiler veya Kökenler) başlıklı eserinde ise Nemrud'un tiranlığı öne çıkarılmıştır. Nemrud'un tiran anlamına geldiğini iddia eden İsidore, Augustinus'un görüşünü paylaşarak, zorba bir yönetim tesis eden Nemrud'un Tanrı ile boy ölçüşmeye kalkarak "Dinsizlik Kulesi” olarak adlandırdığı Babil Kulesi'ni inşa ettirdiğini yazmaktadır. ${ }^{32}$ İsidore'nin Nemrud'un zalim bir idareci olduğuna ilişkin vurgusu, adil bir yönetimin nasıl olması gerektiği konusunda düşünen Salisbury'li John (ö. 1180) gibi düşünürleri etkilemiştir. Aquina'lı Tomasso'dan bir yüzyll önce adil yönetim konusunda düşüncelerini ortaya koyan Salisbury'li John, “güçlü kuvvetli bir avcı olan” ve Tanrı'ya karşı çıkan Nemrud'un

27 Eski Ahit, Yaratılış, 10: 9 http://kutsalkitap.info/tr-gen10.html (eriş. tar. 23 Aralık 2016)

28 St. Augustinus, The City of God: Books VIII-XVI, çev. Gerald G. Walsh ve Grace Monahan (Washington: The Catholic University of America Press, 2008), 490-491.

29 St. Augustinus, The City of God, 433

Dîvân

$2016 / 2$

30 St. Augustinus, The City of God, 511.

31 St. Augustinus, The City of God, 496.

32 Isidore of Seville, The Etymologies, çev. ve haz. Stephen A. Barney, W. J. Lewis, J. A. Beach ve Oliver Berghof (Cambridge: Cambridge University Press, 2006), 7: vi, 163. 
insanların doğal haklarını hiçe sayarak onları köleleştirdiğini söylemektedir. ${ }^{33}$

Nemrud imajını bilinçli olarak kullanan Fortescue'nün, bir hukukçu ve siyaset düşünürü olarak, bu kaynakları bildiğinden şüphe yoktur. Fortescue'nün katkısı, Nemrud figürüne siyaset ve yönetim konusundaki yorumlarında keyfî idareyle özdeş olarak gördüğü Krallık Yönetimini tanımlamada merkezî bir rol vermesidir. Fortescue için Nemrud, kendi arzu ve isteklerine göre kararlar alan ve uygulayan bir kraldır. Tebaasının haklarını ve düşüncelerini kesinlikle gözetmez. "İnsanları güç kullanarak kendine boyun eğdiren Nemrud” böylece “sadece Krallık Yönetimi” denilebilecek bir idari yapı oluşturmuştur. Fortescue, bu açıdan bakıldığında Kutsal Kitap’ın onu kral olarak adlandırmamasını gayet anlaşılır bulmaktadır. ${ }^{34}$ Böyle bir yöneticinin neden Kral olarak adlandırılamayacağı konusunda yine kendinden öncekilerin yazdıklarına dönen Fortescue, Ortaçağ siyaset düşüncesi içinde bilinen bir kavramsallaştırmaya başvurur. Fortescue'ya göre, Nemrud'un Eski Ahit'te kral olarak adlandırılmamasının nedeni kral anlamına gelen "rex" kelimesinin Ortaçağ siyaset düşünce geleneği içinde nasıl algılandığıyla ilişkilidir. Aziz Augustinus, Sevilya'lı İsidore, ve Salisbury’li John gibi, Ortaçağ siyaset düşüncesi denilince akla ilk gelen düşünürlerin hepsine göre kral kelimesi regendo/recendom, yani yönetmek anlamını taşır. Yönetmekten anlaşılan ise, kralın tebaasını onlarla uyumlu şekilde yönlendirmesi ve gözetmesidir. Sevilya'lı İsidore’nin belirttiği üzere, Kral demek olan “rex” kelimesi “doğru biçimde yönetmek" anlamına gelmektedir. ${ }^{35}$

\section{Teo-Politik Analizden Tarihsel Yoruma}

Fortescue’nün “rex” kavramını Nemrud örneğiyle kaynaştırarak, Siyasal ve Krallık Yönetimi’nin nasıl olması gerektiğini gösterdiği yaklaşımı, İngiltere'nin siyasal ve hukuki geleneğinin bu yönetim şekline en uygun koşulları sağladığını iddia ettiği noktada olduk-

33 John of Salisbury, Policraticus: Being a Translation of the First, Second, and on.org/salisbury/policrat123.htm (eriş. tar. 25 Aralık 2016).

34 Fortescue, The Governance of England, 85.

35 Isidore, The Etymologies, 9: iii, 200. 
ça özgün bir karakter kazanır. Aquina'lı Tomasso'nun Aristotelesçi yorumuna sadık kalarak insanların daha iyi bir yaşam için "büyük topluluklar" halinde yapılandıkları söyleyen Fortescue, bunun Britanya topraklarında, efsanevi kurucu Brutus ile birlikte gerçekleştiğini iddia eder. ${ }^{36}$ Tarihsel bir kişilik olduğu oldukça şüpheli olan Brutus hakkında ilk bilgiler, IX. yüzyılda yaşamış Galler’li bir keşiş olan Nennius'a atfedilen Historia Brittonum'da (Britonların Tarihi) görülmektedir. Kökenleri Truvalılara dayandırılan Brutus'un Britanya'yı kurduğu efsanesine XII. yüzyılda yaşamış olan din adamı ve tarihçi Geoffrey Monmouth'un (takriben ö. 1155) Historia Regum Britanniae (Britanya Krallarının Tarihi) kitabında kapsamlı biçimde yer verilmiştir. ${ }^{37}$ Monmouth'un eserinin Ortaçağ İngiltere'sinde okuma yazma bilen kesimler içinde oldukça yaygın olarak okunduğu bilinmektedir. Fortescue'nün bu efsaneyi bilmesi ve kullanması bu bakımdan oldukça doğaldır. Öte yandan, Brutus efsanesi İngiliz milli kimliğinin Fransız karşıtlığıyla şekillendiği ve İngilizce'nin yazı dili olarak kullanılmaya başlandığı Geç Ortaçağ İngiliz kültüründe popüler hale gelmiştir. Öyle ki, dönemin en iyi bilinen ve çokça okunan Ortaçağ İngilizcesi ile yazılmış ve Brutus’tan, kroniğin yazar tarafından bitirildiği tarihe kadarki döneme kadar, anonim olarak yazılan Brut kronikleri adını bu efsaneden almıştır. ${ }^{38}$

Brutus efsanesinin Geç Ortaçağ İngiliz insanının zihnindeki canlılığını bilen Fortescue, böylece efsaneyi teo-politik okumasıyla birleştirerek, siyaset düşüncesini tarihselleştirme yoluna gider. Fortescue, İngiliz geleneğinde Siyasal ve Krallık Yönetim tarzının eskiliğini vurgularken Ortaçağ siyaset düşüncesinin siyasal toplumu organik bütünlük (corpus politicum) olarak kavraması eğilimini takip eder. Bu noktada da, bir Geç Ortaçağ siyaset düşünüründen beklenecek şekilde, eskilerin yazdıklarına döner. Aziz

36 Fortescue, In Praise of the Laws of England, 22. Fortescue, The Governance of England, 86.

37 Nennius, History of the Britons (Historia Brittonum), çev. J. A. Giles (Cambridge, Ontario: In Parantheses Publications, 2000), 4-10. Goeffrey of Monmouth, History of the Kings of Britain, çev. Aaron Thompson, ed., J. A. Giles (Cambridge, Ontario: In Parantheses Publications, 1999), 2-22.

38 Chris Given-Wilson, Chronicles: The Writing of History in Medieval England (Hambledon: London, 2004), xxii, 3, 216. Fatih Durgun, “Geç Ortaçağ İngiliz Kroniğinin Analizi: London Chronicles'ın Cotton Julius B II Nüshasında Siyasi Belge Kullanımı Üzerine Bir İnceleme," Tarih Araştırmaları Dergisi 39 (2016): 43-62, özellikle 44-46.

\section{Dîvân}

$2016 / 2$ 
Augustinus'un, insanların "yasaların rızasıyla ve çıkar topluluğu" olarak bir araya geldiklerini yazdığını belirten Fortescue, nasıl ki "beden fiziksel embriyodan doğuyor ve baş tarafından yönetiliyorsa, bir Krallık da insan topluluğundan kaynaklanıp mistik bir beden olarak var olur ve vücuttaki başa karşılık gelen bir kişi tarafından yönetilir." demektedir. ${ }^{39}$ Corpus Mysticum (Mistik Beden) Ortaçağ'da bilinen ve kullanılan bir kavramdır. Bu konuda kapsamlı ve analitik bir inceleme yapmış olan büyük Alman tarihçi Ernst H. Kantorowicz, Kurumsal Kilise'nin seküler otoriteyle çatışma içinde olduğu Yüksek Ortaçağ’da Corpus Mysticum'un, bütün bir inananlar topluluğunca oluşturulan Kilise'nin “İsa'nın mistik bedeni" anlamında kullanılmaya başlandığını; kavramın dünyevi bir kurumu nitelendirmek için kullanılmasının dinî içeriği aşındırdığını göstermiştir. Aquina'lı Tomasso gibi teologların dinî içeriği esas alarak kullandıkları kavram, Kilise ile İsa özdeş görüldükçe, İsa'nın bedeninin (Corpus Christi) organik toplum ve devletle özdeşleştirilmesine doğru giden farklı bir eğilimi de güçlendirmiştir. ${ }^{40}$ Fortescue'nün siyasal toplumu Corpus Mysticum olarak görmesi bu ikinci yaklaşımın yansımasıdır.

Corpus Mysticum siyasal toplumla özdeşleştirilince dinî olduğu kadar tarihsel olarak da meşrulaştırılması zorunlu hale gelir. Fortescue bu nedenle Brutus ve tebaasının siyasal toplumu kurarken, tıpkı vücudun başa ihtiyaç duyması gibi, tebaanın da kendilerini yönetecek bir lidere ihtiyaç duyduğunu ve Brutus'u siyasal topumun başına kral olarak atadıklarını belirtir. ${ }^{41}$ Bunu seçimle yapıp yapmadıkları konusu muğlak görünür. Kralı bir toplumun başındaki tek meşru idareci olarak gören Fortescue'nün asıl meselesi de zaten bu değildir. Onu ilgilendiren, Krallık Yönetimini keyfî idareyi sapmaktan alıkoyan Siyasal ve Krallık Yönetimi'nin kurulmasıdır. Bu bağlamda, Fortescue'nün siyasal olandan ne anladığı burada bir diğer dikkate değer husustur. Policia kelimesinin poles, yani pek çok kelimesiyle $y$ cos, yani bilgelik kelimesinin birleşiminden meydana geldiğini iddia eden Fortescue'ya göre siyasal yönetim bilgelik ile meşveretin bir araya geldiği bir yönetim biçimi anlamındadır. ${ }^{42}$ Fortescue'nün Policia kelimesini bu biçimde tanımlaması öncel-

Dîvân

2016/2

39 Fortescue, In Praise of the Laws of England, 20.

40 Ernst H. Kantorowicz, The King's Two Bodies: A Study in Medieval Political Theology (Princeton: Princeton University Press, 1957), 193-206.

41 Fortescue, The Governance of England, 86.

42 Fortescue, The Governance of England, 86-87. 
lerinde görülmez. Klasik Aristotelesçi anlayışta polise ilişkin işleri ifade eden ve Ortaçağ'da organik Hristiyan bir toplumun idaresiyle ilişkilendirilen Policia, Fortescue'da çoğul olan anlamında kullanılır. Benzer bir kullanım Lucca'lı Ptolemy'de de görülür. Ptolemy, polis kelimesinin çoğunluk ve kent anlamlarına geldiğini yazar. ${ }^{43}$ Ptolemy'i okuyan Fortescue, bu kavramsallaştırmayı ondan almış olabilir. Burada çoğunluk ile ifade edilen çoğulcu bir yönetim değildir. Fortescue'nün vurguladığı krallık görevini üstlenen yöneticinin, tebaasının haklarını koruması, etrafındakilerin tavsiyelerine ve kadim hukuk geleneğine uymasıdır.

Policia kelimesini Siyasal ve Krallık Yönetiminin dengeleri gözeten doğru yönetim biçimi olduğunu göstermek için kullanan Fortescue, önerdiği siyasal yönetimin tarihsel kökenlerini ispatlamaya çalışırken sadece İngiltere örneğiyle sınırlı kalmaz. İskoçların da bu ilkeye göre yönetim sistemi geliştirdiklerini belirterek, Mısır Medeniyeti ve Libya gibi yerlerde de eski zamanlarda insanların rızasına dayalı yönetim şeklinin görüldüğünü vurgular. Bu ülkelerde Krallık ve Siyasal Yönetim'in nasıl olduğunu anlatırken, M. Ö. I. yüzyılda yaşamış Yunan tarihçi Diodorus Siculus'un (Sicilya'lı Diodorus Siculus), Avrupa'da Doğu hakkında ilgi ve malumatın artmasına paralel olarak, ilk 5 kitabı XV. yüzyılda İtalyan hümanist Poggio Bracciolini tarafından Yunancadan Latinceye çevrilen Bibliotheca Historica (Tarih Kütüphanesi) adlı eserini kendine kaynak olarak kullanır ${ }^{44}$ Siculus'un anlatısındaki bazı kısımlar gerçekten de Fortescue'nün Siyasal ve Krallık Yönetimi biçimini meşrulaştırmasına yarayacak bilgiler sunar. Örneğin, Fortescue, Siculus'un 4. kitabına referansla eski zamanlarda Etiyopya Kralının ülkesinin "kadim yasalarına göre hareket ettiğini" ve bütün uygulamalarını "atalarından miras kalan yasalara göre" gerçekleştirdiğini söyler. ${ }^{45}$ Böylece, John Fortescue İngiltere ve Doğudan verdiği örneklerle önerdiği kavramsallaştırmanın meşruiyeti ve tarihselliğini iyice pekiştirir.

Siyasal Yönetimin Kaynağı Olarak Hukuk

43 Ptolemy of Lucca, On the Government of Rulers, Book IV, Chapter 1, 216. 44 Fortescue, In Praise of the Laws of England, 22.

45 Fortescue, The Governance of England, 87. 
Fortescue'nün düşünce dünyasında Siyasal ve Krallık Yönetiminin dinî ve tarihî temellendirmesi hukuki temellendirmeden ayrı düşünülmez. Örfi hukuk eğitiminden geçmiş bir hukukçu olan Fortescue için İngiliz hukuk geleneği, kadim niteliği ve sürekliliğiyle bu yönetim biçimine en uygun zemini oluşturur. Fortescue, Ortaçağ hukuk düşüncesinin Aristotelesçi temel niteliklerine sadık kalır. Doğal Hukuk (law of nature) değişmez biçimde bütün insanlar için geçerlidir. Aquina'lı Tomasso'nun ifadesiyle “insanoğlu yaşamı için gerekli olan özel şeylerin bilgisini akıl yürütmeyle doğal ilkelerden çıkarır." ${ }^{46}$ Fakat kendi yargısıyla "bütün her şeyin bilgisine ulaşması mümkün değildir.” ${ }^{47}$ Hem topluluk yaşamının devamının hem de toplumun adil bir şekilde işleyebilmesinin bütün insanlar için değişmez çerçevesi böylece tanımlanır. Bu bağlamda, Aristoteteles'in Etik'ine atıfta bulunan Fortescue, Doğal Hukuk'un bütün insanlar için aynı etkiye ve güce sahip olduğunu vurgular. ${ }^{48}$ Fakat gelenekler ile çerçevesi çizilmiş yasalar aracılılığıyla milletlerin hukuk sistemi arasında farklılıklar meydana gelir. İngiltere'nin gelenekleri tarihi süreç içinde hem yöneticiler hem de tebaanın rızasıyla benimsenmiş ve esas olarak kabul edilmiştir. İngiliz hukuk geleneği eski olmasının yanı sıra en iyi iyisidir de. Fortescue'nün, İngiliz yasalarının eskiliğini övmesi bu yasaların eskiliğinden dolayı en iyi olduğu anlamına gelmez. En iyi olmasının nedeni "yalnızca hükümdarın iradesiyle yapılmamış” olmasıdır. Herkesin "rızası" ile yapılan yasalar özleri itibariyle değişmez biçimde kalmışlardır. Tebaanın onayı ile yapılmalarının İngiliz yasalarını en iyi olarak değerlendirmeyi mantıklı hale getirir. Çünkü insanların kendi rızalarıyla yaptıkları yasa “onlara zarar verecek” ya da onların menfaatleriyle çatışacak nitelikte olamazlar. ${ }^{49}$

Bu anlamda, hukuk kişileri siyasal topluma dönüştürme yönüyle Siyasal ve Krallık Yönetimi biçiminin odağında yer alır. Yasalar siyasal toplumun kuruluşundan itibaren rıza ile oluşturulduklarından, kral için de bağlayıcı hükme sahip olurlar. İşte tam da bu noktada, Fortescue için İngiliz örfi hukuk geleneği bir yönetim biçiminin nasıl olması gerektiği konusunda Kıta Avrupasındaki Kamu

46 Aquinas, De Regno, Book I, Chapter 1: 6. http://dhspriory.org/thomas/DeRegno.htm (eriş. tar. 26 Aralık 2016).

47 Aquinas, De Regno, Book I, Chapter 1: 6. http://dhspriory.org/thomas/DeRegno.htm (eriş. tar. 26 Aralık 2016).

48 Fortescue, In Praise of the Laws of England, 26.

49 Fortescue, In Praise of the Laws of England, 27. 
Hukuku (Civil Law) geleneğinden farklılık ve üstünlüğü bünyesinde barındırır. Kıta Avrupa'sındaki Kamu Hukuku, bilindiği üzere Bizans İmparatoru Jüstinyen döneminde derlenen ve Corpus Juris Civilis (Kamu Hukuku Külliyatı) olarak bilinen Roma hukuk sistemine dayanmaktadır. Corpus'un yönetime ilişkin maddelerinden birisi de "Hükümdarı hoşnut eden her ne ise o, kanun hükmündedir." (quod principi placuit legis habet vigorem). Roma geleneğinde lex regia (krallık hukuku) olarak bilinen ilkeyi belirten bu madde, Roma cumhuriyetten imparatorluğa dönüşürken halkın yönetime dair bütün hak ve yetkilerini İmparator'a devretmesini simgeler. Bu andan itibaren, mutlak otoriteyle yetkilendirilmiş İmparator yaşayan yasa (lex animata) niteliğini kazanır. ${ }^{50}$ Fortescue, bu maddenin Kıta'daki Krallık Yönetimini ve siyaset sistemini şekillendirdiğini iddia etmektedir. İngiltere'deki örfi hukukla sınırlandırılmış Krallık Yönetiminin zıddı olarak Roma Kamu Hukuku'nun yönetim anlayışının, yani kralın keyfî idaresine yol açacak Krallık Yönetiminin en bariz örneği olarak Fransa'yı göstermektedir. De Laudibus'ta Fransa'da Roma Kamu Hukuku'na bağlı Krallık Yönetimi olması nedeniyle, Kamu Yararı ilkesinin gözetilmediğini dile getiren Fortescue, Kral adayı Prens Edward'a Fransa'da sürgünde geçirdikleri dönemde Fransa'da şahit oldukları halkın sefaletini unutmaması gerektiğini belirtir. Buna karşılık, İngiliz Örfi Hukuku'nun çerçevesini çizdiği İngiliz Siyasal ve Krallık Yönetiminin, keyfî idarenin önüne geçen bir “Adalet” mekanizmasını, "Kamu Yararı”nı dikkate alarak, tarihî süreç içerisinde tesis ettiğini iddia eder. ${ }^{51}$

\section{Sonuç: Fortescue'nün Siyaset Düşüncesinin Tarihselliği}

John Fortescue'nün siyaset ve yönetim düşüncesinin temel taşları bu şekilde, Örfi Hukuk üzerine inşa edilmiş bir teo-politik ve tarihsel çözümlemeyle yerli yerine oturur. Fortescue'nün Siyasal ve Krallık Yönetim Biçimi kavramsallaştırması özgün olmakla birlikte, İngiliz anayasalcılığına kapı açacak bir meta anlatı olarak tasarlanmamıştır. Fortescue, bir siyaset teorisyeni olmakla beraber, pragmatik bir siyasetçi ve hukukçudur. Hedefi, döneminin hâkim siyasal düşüncelerini hukukçu olarak edindiği formasyonla bütün-

50 Joseph Canning, A History of Medieval Political Thought: 300-1450 (London: Routledge, 2005), 8.

51 Fortescue, In Praise of the Laws of England, 49-53. 
leştirip, içinde bulunduğu siyasal konjonktüre dair bir siyaset ve yönetim biçimi önermektir. Bu hem yaptığı kavramsallaştırmayı hem de yazdığı bütün metinleri tarihsellikleri içinde değerlendirmeyi zorunlu kılar.

Fortescue'nün siyaset anlayışı değerlendirilirken öncelikli olarak dikkat edilmesi gereken nokta, Ortaçağ İngilteresinin, belki diğer bütün Ortaçağ Avrupa Krallıklarında olduğu gibi, kralın otoritesinin sınırlarının ne olacağına ilişkin büyük bir çelişkiyle boğuşmak zorunda olduğuydu. Teorik olarak durum şöyleydi: Kral, siyaset kurumunun merkezinde mutlak otorite kabul edilmeliydi ve onun iradesi son kertede belirleyici ve tartışılmazdı. Tebaasının hukukunu ve mutluluğunu teminat altına alması gerektiğine ilişkin geleneksel düşünceye dayandığı sürece, otoritesi sorgulanamaz nitelikteydi. John Watts'ın oldukça açıklayıcı bir şekilde ifade ettiği gibi, kralın, bir kral olarak iradesinin iki yönü vardı. Kralın bir karar alırken kullandığı "şahsi iradesi” olmalıydı. Bu vazgeçilmez bir husustu. Diğer taraftan ise, kralın kendi tebaasıyla oluşturduğu bir "Kamusal İradesi" vardı. İradenin kamusal haline gelişi kralın etrafındaki danışmanlarıyla veya ülkenin ileri gelenleriyle istişaresi sonucunda karar almasıyla ortaya çıkıyordu. Fakat bir karar alırken, kralın kendi inisiyatifini kullanması gerekirdi. İnsiyatif kullanamayan ve doğru kararlar alamayan bir kral zaten meşverete uygun davranmiyor demekti. ${ }^{22}$

Kral-tebaa ilişkisinin bu kadar karmaşık olduğu düzen, ${ }^{53}$ özellikle kralın zayıf olduğu, kendi isteklerini tebaasına dayattığı veya böyle algılandığı dönemlerde büyük siyasal krizlere yol açmıştı. Fortescue'nün kendine referans aldığı ve üzerinde durduğumuz Ortaçağ siyaset düşüncesi, ortaya çıkan bu hassas duruma karşı çözüm bulma temelinde gelişmiş ve şekillenmişti. İngiliz tarihi de bu tür siyasal kriz örnekleriyle doluydu. Bu durum karşısında İngiliz Ortaçağ hukukçuları hukukun üstünlüğünü yerleştirmeye çalışmışlardı. İngiliz Örfi Hukuk geleneğinin şekillenmesinde büyük rol oynamış olan Henry Bracton (ö. 1268) "Kralı kral yapan,

$53 \mathrm{Bu}$ kafa karışıklığı Fortescue'nün siyaset düşüncesinde belirgindir. Kralın nasıl sınırlandırılacağı hala muğlak gibidir. Fortescue'de kralın iradesiyle ilgili anayasalcı perspektiften eski bir okuma için bkz. James L. Gillespie, "Sir John Fortescue's Concept of Royal Will," Nottingham Medieval Studies 23 (1979): 47-65, özellikle 55-65. 
yasadır." ${ }^{54}$ diyecek kadar ileri gidebilmişti. Kral John ve soylular arasında yaşanan mücadele neticesinde 1215 yılında ilan edilen Magna Carta' ya yol açan siyasal kriz ve sonrasındaki hukuk vurgusu belki Fortescue için çok uzak bir tarihte kalmıştı, fakat Fortescue hayatı boyunca hizmetinde bulunduğu Lancaster Hanedanı'nın iktidara gelişini çok iyi biliyordu. IV. Henry, kuzeni II. Richard'ı 1399 yılında devirip Hanedanı tesis ettiğinde kendi iktidarını meşrulaştırmak için resmî belgelerde ve söylemlerinde, Richard'ın aksine, kral ve tebaası arasında "Kamu Yararı" temelinde bir ilişki kuracağını vurgulamıştı. ${ }^{55}$ Fortescue'nün Siyasal ve Krallık Yönetimini kavramsallaştırdığı Lancaster Hanedanı'nın son günlerinde ise, Kral "Kamu Yararı"nı gözetmemekle suçlanıyordu. Zaten York ailesi etrafında gelişen ve nihayetinde York Hanedanı'nın ülke yönetimini mutlak surette ele geçirmesiyle sonuçlanan süreç bunun sonucuydu. Fortescue, 1453 yılında akli melekelerini tamamen yitirmiş ve iradesini kullanmaktan yoksun olan VI. Henry'nin oğlu Edward'a Siyasal ve Krallık Yönetiminin doğruluğunu anlatırken, Lancaster Hanedanı'nın iktidara gelişindeki “Kamu Yararı” prensibine vurgu yapmayı gerekli görüyordu. Krallığın zorunluluğunu ve bir toplum için vazgeçilmez olduğunu düşünen Fortescue için, ${ }^{56}$ şahsi iradesini "kamusal irade" ile bütünleştirecek bir kral siyasal krizi bitirebilirdi. Kamusal iradenin tezahürü İngiliz hukuk geleneğine uygun kararlardan geçiyordu. Kuşkusuz bunu için meşveret sisteminin işletilmesi gerekirdi. Fakat Fortescue'ye göre bu, eski yöntemlerle olamazdı. Kral'ın Danışma Meclisi, sadece kendi işleriyle ilgilenip Kral'ın, dolayısıyla ülkenin meselelerini ihmal eden geleneksel aristokrasiden oluşuyordu. Bunun değişmesi, dolaysız olarak Kral'a bağlı bir Danışma Meclisi oluşturulması gerektirmekteydi. ${ }^{57}$ Fortescue, içinden geldiği zümrenin kalbinden geçenleri dillendiriyordu. Kriz içindeki devlet ve toplumu ancak profesyonelleşen hukukçular huzura kavuşturabilirdi.

54 Cromartie, "Common Law, Counsel and Consent," 45-68.

'The Record and Process of the Deposition of Richard II," History of Political Thought 25 (2004): 599-619.

56 Cromartie, "Common Law, Counsel and Consent," 45-68.

57 Fortescue, The Governance of England, 114-115. Watts, Henry VI, 46-51. 


\section{Kaynakça}

Arrowood, Charles F. "Sir John Fortescue on the Education of Rulers.” Speculum 10 (1935): 404-410.

Aquinas, Thomas. De Regno Ad Regem Cypri. Çev. Gerald B. Phelan, göz. geç. I. Th. Eschmann. Toronto: The Pontifical Institute of Mediaeval Studies, 1949. http://dhspriory.org/thomas/DeRegno. htm (eriş. tar. 15 Aralık 2016).

Burns, J. H. "Fortescue and the Political Theory of Dominium." Historical Journal 28 (1985): 777-797.

Blythe, James M. Ideal Government and the Mixed Constitution in the Middle Ages. Princeton: Princeton University Press, 1992.

Canning, Joseph. A History of Medieval Political Thought: 3001450. London: Routledge, 2005.

Chrimes, S. B. "Sir John Fortescue and His Theory of Political Dominium.” Transactions of the Royal Historical Society, 4. Seri, 17 (1934): 117-147.

Cromartie, Alan. "Common Law, Counsel and Consent in Fortescue's Political Theory." The Fifteenth Century IV: Political Culture in Late Medieval Britain. Ed. Linda Clark ve Christine Carpenter, 45-68 (Woodbridge: The Boydell Press, 2004).

Durgun, Fatih. “Geç Ortaçağ İngiliz Kroniğinin Analizi: London Chronicles'ın Cotton Julius B II Nüshasında Siyasi Belge Kullanımı Üzerine Bir İnceleme.” Tarih Araştırmaları Dergisi 39 (2016): 4362.

Ferguson, Arthur B. "Fortescue and the Renaissance: A Study in Transition." Studies in the Renaissance 6 (1959): 175-194.

Fortescue, John. "In Praise of the Laws of England.” Sir John Fortescue: On the Laws and Governance of England, ed. Shelley Lockwood, 3-80. Cambridge: Cambridge University Press, 2002.

Fortescue, John. “The Governance of England.” Sir John Fortescue: On the Laws and Governance of England, ed. Shelley Lockwood, 83-123. Cambridge: Cambridge University Press, 2002.

Dîvân

Fortescue, John. "Extracts from On the Nature of the Law of $\mathrm{Na}$ ture." Sir John Fortescue: On the Laws and Governance of England, ed. Shelley Lockwood, 127-136. Cambridge: Cambridge University Press, 2002. 
Goeffrey of Monmouth. History of the Kings of Britain. Çev. Aaron Thompson, ed. J. A. Giles. Cambridge, Ontario: In Parantheses Publications, 1999.

Gilbert, Felix. "Sir John Fortescue's Dominium regale et politicum." Medievalia et Humanistica 2 (1944): 88-97.

Gillespie, James L. “Sir John Fortescue’s Concept of Royal Will.” Nottingham Medieval Studies 23 (1979): 47-65.

Gill, P. E. "Politics and Propaganda in Fifteenth- Century England: the Polemical Writings of Sir John Fortescue." Speculum 46 (1971): 337-347.

Given-Wilson, Chris. Chronicles: The Writing of History in Medieval England. Hambledon: London, 2004.

Goss, E. Robert. "The First Meeting of Catholic Scholasticism with dGe lugs Pa Catholicism.” Scholasticism: Cross-Cultural and Comparative Perspectives, ed. José Ignacio Cabezón, 65-90. New York: State University of New York Press, 1998.

Hinton, R. W. K. "English Constitutional Doctrines from the Fifteenth Century to the Seventeenth: I. English Constitutional Theories from Sir John Fortescue to Sir John Eliot.” EHR 75 (1960): 41042.

Isidore of Seville, The Etymologies. Çev. ve haz. Stephen A. Barney, W. J. Lewis, J. A. Beach ve Oliver Berghof. Cambridge: Cambridge University Press, 2006.

John of Salisbury. Policraticus: Being a Translation of the First, Second, and Third Books and Selections from the Seventh and Eighth Books. Çev. Joseph B. Pike. New York: Octagon Books, 1972. http://www.constitution.org/salisbury/policrat123.htm (eriş. tar. 25 Aralık 2016).

Kantorowicz, Ernst H. The King's Two Bodies: A Study in Medieval Political Theology. Princeton: Princeton University Press, 1957.

Kelly, M. R. L. "Sir John Fortescue and the Political Dominium: The People, the Common Weal, and the King." Constitutions and the Classics: Patterns of Constitutional Thought from Fortescue to Bentham, ed. D. J. Galligan, 51-85. Oxford, Oxford University Press, 2014.

Lockwood, Shelley. “Introduction.” Sir John Fortescue: On the Laws and Governance of England, xv-xxxix.Cambridge: Cambridge University Press, 2002. 
Nederman, Cary J. "From Moral Virtue to Material Benefit: Dominium and Citizenship in Late Medieval Europe." Cultivating Citizens: Soulcraft and Citizenship in Contemporary America, ed. Dwight D. Allman \& Michael D. Beaty, 43-60. New York: Lexington Books, 2002.

Nennius, History of the Britons (Historia Brittonum). Çev. J. A. Giles. Cambridge, Ontario: In Parantheses Publications, 2000.

Orme, Nicholas. "Education and Recreation." Gentry Culture in Late Medieval England, ed. Raluca Radulescu \& Alison Truelove, 63-83. Manchester: Manchester University Press, 2005.

- Medieval Schools: From Roman Britain to Renaissance England. New Haven: Yale University Press, 2006.

Ptolemy of Lucca. On the Government of Rulers, de Regimine Principum. Çev. James M. Blythe. Philadelphia: University of Pennsylvania Press, 1997.

Skinner, Quentin. The Foundations of Modern Political Thought: The Age of Reformation. Cilt 2, 11. Edisyon. Cambridge: Cambridge University Press, 2004.

St. Augustinus. The City of God: Books VIII-XVI. Çev. Gerald G. Walsh ve Grace Monahan. Washington: The Catholic University of America Press, 2008.

Theilmann, John. "Caught Between Political Theory and Political Practice: 'The Record and Process of the Deposition of Richard II.'” History of Political Thought 25 (2004): 599-619.

Watts John. Henry VI and the Politics of Kingship. Cambridge: Cambridge University Press, 1996. 


\title{
ORIGINALITY AND CONTINUITY IN MEDIEVAL EUROPEAN PO- LITICAL THOUGHT: THE HISTORICITY OF JOHN FORTESCUE'S UNDERSTANDING OF POLITICS AND ADMINISTRATION
}

\begin{abstract}
John Fortescue was the most important political thinker of Late Medieval England and his political writings are still the subject of heated debates among scholars. As a jurist and statesman, Fortescue wrote his works in a period of political and social disorder known as the Wars of the Roses, when Lancastrians and Yorkists were engaged in a civil war for the English Crown. Fortescue made a very authentic contribution to the history of political thought through his distinction between the concept of Royal Rule (dominium regale) and his own conceptualization of Political and Royal Rule (dominium politicum et regale). In Fortescue's thought, while Royal Rule characterizes the position of a king with absolute authority, Political and Royal Rule describes a system wherein the king looks to secure the support of his subjects in the decision-making process and where his will is limited through English Common Law. Fortescue's conceptualization has been considered an obvious instance of English Constitutionalism by those arguing that English political thought was distinct from that in Continental Europe. On the other hand, it has been asserted that Fortescue's political understanding was distinct from traditional theologybased medieval political theory, since he was a secular jurist. Fortescue's historical context, however, has been neglected. This article offers a reading of Fortescue's political works within their political and historical contexts. As opposed to the prevailing view, this study argues that Fortescue's political thought was not an encompassing meta-narrative addressing future generations. Fortescue's political understanding sought a solution to the political and social crisis of his time, and he never aimed at thinking outside the box of traditional medieval political thought. The essential value of his thought is the perspective it offers on the conditions of the newly emerging body of professional jurists during the period, and that it does so firmly within the bounds of Medieval thought.
\end{abstract}

Keywords: John Fortescue, Late Medieval, England, Political Thought, Political and Royal Rule 